\title{
Informal Networks of Power and Control of Deviation in Post-Soviet Non-Democracies
}

\author{
Nicolas Hayoz \\ University of Fribourg, Fribourg, Switzerland
}

\begin{abstract}
Informal networks, practices and institutions may be observed in many different social contexts, particularly in politics. In certain political regimes, certain forms of informality are to be expected and are also tolerated more than in others. Political informality in Eastern Europe may be presented on an axis with two poles, with many variants or combinations of informality and formality between them. These positions also allow the identification of specific regime types and legal systems. This chapter seeks to contextualize the distinction between the formal and the informal and to relate it to types of political regime, the principal focus resting on informal politics. Specific political contexts may produce practices of informality that have become so generalised that they can be described as cultures of informality. The interesting question is: to what extent are specific forms of informal structures more resilient in particular regime types than in others? Particularly looking at some of the more-or-less autocratic Euroasiatic states, one can easily recognize that the very purpose of informal politics and institutions is to restrict or eliminate political competition. Forms and meanings of what is informal and formal change the further one moves eastwards. Formal rules are and may be used together with informal institutions to control society. All this points to specific cultures of informality that can be observed, as well as different cultures of trust and distrust. On the other hand, such cultures of informality have to be considered in the context of specific political systems, together with their regimes (the concrete configurations of political power) and their organisations. This paper looks particularly at hybrid non-democracies and suggests one might consider them, in the perspective of Niklas Luhmann's system theory, as parasites of functional differentiation.
\end{abstract}

Keywords: informal politics, informal networks, authoritarian regimes, Russia, functional differentiation, legal nihilism

\section{Introduction}

However, observed or alleged differences should not lead to the conclusion that differences between "Western informality" and "Eastern informality" are fundamental. They are probably not very different from what anthropologists and sociologists have observed with regard to differences between countries of the "global South" and the northern Organisation for Economic Co-operation and Development (OECD) countries. "Informal cultures" are not a privilege of the South or the East and neither is Max Weber's universal reign of legal norms the privilege of the North. Differences and divergences between norms and practises exist everywhere. That also goes for the difference between "good informality", which would be "compatible" with democracies, and "bad informality": the former is not concentrated in the West and the latter cannot be

Nicolas Hayoz, Associate Professor, Department of Social Sciences, Institute for Eastern Europe, University of Fribourg. 
associated with the South or the East (Steinsdorff, 2005). The interesting question, then, is how norms and practices are "continually produced and recomposed" by social actors (Olivier de Sardan, 2013, p. 78). Obviously, the reproduction of specific patterns of the interplay between formal and informal structures and practices is also dependent on political and cultural contexts. Certain patterns, such as highly personalized networks of power, may be more typical of post-Soviet contexts. It may make sense, then, to establish ideal types of informal institutions such as "tradition-based institutions" or "transition-based institutions" (Köllner, 2012 , p. 16) and/or to ask about the effectiveness of informal and formal institutions, as in the case of the typology of Helmke and Levitsky (2004).

Moreover, beyond the question of the relationship between informality and regime types, regional variations of the interplay between the formal and the informal should also be considered in the context of another distinction - the dominant conceptions of order and disorder in society, which points to the type of modernity accepted in a regional society. The modernity and complexity of social systems can be seen in their capacity to cope with order and disorder and - as we may add here-with formality and informality (Van Assche, Breunen, \& Duineveld, 2014). Disorder and order participate together in the reproduction of any organizational order or system. ${ }^{1}$ Order produces disorder, particularly in authoritarian regimes trying to avoid the disorder of deviation and opposition. An examination of protest movements in authoritarian or illiberal regimes is instructive: in most cases their protest is turned against the officially "prescribed" order, reclaiming precisely the conditions and freedoms of a modernity denied by the regime. For example, the protest movements of 2011-2012 in Russia, which could also be described as a manifestation of the informal part of society, precisely the part the regime is so eager to control. If informality is on the side of "disorder", it was protest against the formal order not only of a repressive political regime with its formal illiberal rules, its corrupt oversized bureaucracy and the predatory mentality of its elites, but also against the authoritarian and anti-modern values of a conservative society, which has not yet reached the shores of modern individualism and tolerance, of a modern conception of informality. In that sense it becomes clear that informality can, as Barbara Misztal (2000) has put it, also have the meaning of freedom, of the freedom of actors, of choice of behavior (p. 230). ${ }^{2}$ And in a case such as Russia one may add: informality as a claim of parts of society to be different or as opposition to the established order of formal and informal structures of power and the values propagated by a small elite trumpeting to the world that the regime's policies are in phase with the conservative majority. ${ }^{3}$ Networks and organizations can also be used to "bring back society" with its requests for autonomy and freedom. In any case, the protest against parasitical social structures also involves networks and organizational systems. One could also say: It is modernity reclaimed from a modern distinctions and forms of

\footnotetext{
${ }^{1}$ For this question of dialogue between order and disorder see Morin, 2008: 112ss., 2434, and of course Luhmann (1990), who considers the "construction and reproduction of order out of order and disorder" as basic to the reproduction of self-referential systems (p. 85).

${ }_{2}^{2}$ More generally such a concept of informality understood as freedom or, more precisely as a variable margin of freedom of action in specific contexts, is in line with a sociological tradition in the field of organisation studies (Crozier \& Friedberg, 1977; Ortmann, 2003).

3 Russia displays, like many former communist countries, an exceptional pattern on Inglehart's global cultural map in the sense that it does not follow "the general trend toward increasing emphasis on self-expression values; in fact, Russia showed a retrograde movement toward increasing emphasis on traditional values and survival values" (Ingelhart 2012, p. 140). With the exception of the big cities, there is no question of a "cultural shift" towards more freedom, self-expression values and demands for more democracy, mentalities which would come close to Misztal's understanding of informalisation. Such conclusions are in line with the findings of Russian sociologists such as Gudkov (2012). See also in this regard Ledeneva (2013), who considers the protest movement of December 2011 to be also a critique of systema, of the established informal mode of governance (pp. 250, 255).
} 
differentiation.

Such a kind of informality as freedom or "deviation" finds its counterpart in organisations, as resistance and the capacity on the part of certain members of an organized social structure to negotiate formal rules as well as to manipulate them in order to "beat the system". From the level of "micro-politics" in companies as well as in political organisations to the totalitarian efforts in communist regimes: the history of informal "responses" to planning, control or repression from "above" has always been to develop strategies in order to adapt, undermine or avoid the system. ${ }^{4}$

The way political regimes in particular interact with other organizations, inside and outside of the political system, provides the image of more or less state-controlled, more or less liberal societies. As such they always express a specific power structure too - in the context of both democratized or rather authoritarian regimes. We expect non-democracies to make other, more inflationist use of organizational systems for the purpose of population control, for example. One could also say that democracy or the degree to which a political regime admits political opposition (negation!) and political rights (including the freedom to contest the incumbents of power) is an indicator of its attitude towards the autonomy of the organizational exponents of functional systems, be it political parties, social movements, religious groups, NGOs, minorities, companies, universities, schools, etc.

And consequently, quasi-authoritarian regimes usually based on a dominant party structure also produce as a correlate extensive networks of corruption and clientelism. Hybrid authoritarian regimes in post-Soviet and in many non-western countries rely not only on organizational power but also on personal power and networks and informal practices (Levitsky \& Way, 2010). On the other hand, "anti-modern" corruption practices can also represent a "survival strategy" of people confronted with inefficient formal state organizations (Rose, 2000a; $2000 \mathrm{~b}$ ). It is precisely on this level, in the interaction between organized systems, informal networks and personal power where we can learn how authoritarianism works under modern conditions. Regional and local peculiarities might also involve the reproduction of forms of "secondary" and parasitical differentiation sailing in the fairway of functional differentiation, the dominant structure of modern society (Luhmann, 2012).

\section{Functional and Parasitical Differentiation in Post-Soviet States}

As a matter of fact, differences with regard to corruption, modernisation, personalisation, social and economic disparities or democratisation cannot be the decisive factors for categorizing a country as anything other than modern. Of course, for certain countries it may be helpful, at least on the political level, not to be considered part of the "West", since that would imply the obligation to respect a certain number of rules, for example democracy or human rights. The same may be said with regard to the economic integration into a globalized word economy of countries that do not participate in certain organisations or insist on the coexistence of different forms of capitalism. But even insisting on differences is communication in the context of a globalised world society. Likewise, when states controlling specific territories try to block or control certain achievements of that modernity, such as democracy in the form of political opposition, the legal system with an independent judiciary, or the so-called private sphere with its businesses, organizations and associations, they do that under the conditions of functional differentiation. In that sense, for Niklas Luhmann (2012)

\footnotetext{
4 James Scott (1998, pp. 310, 352; 2012) pointing to many impressive examples taken not only from communism's "big intentions" to show that formal rule could not reach out to reality without its informal counterpart and that "nonconforming practice is an indispensable condition for formal order".
} 
"functional differentiation of society also has so strong a hold on world society that it cannot be regionally boycotted by even the most drastic of political and organizational means" (p. 92).

So when asking, from the perspective of political sociology, how or to what extent the idea of functional differentiation is being "realized", "controlled" "questioned" or even "undermined" on a regional level, one would most probably point first to the states of the political world system. States and organized groups of states are (still) the main spaces where huge organizational capacities are developed, for example to enhance globalization or to control society. And as holders of state power they can use state organs and organizations to control other organizations on the territory of their jurisdiction. And the degree to which they are able to do that is obviously also dependent on the more or less democratic constitution of political power. The degree of democratization also determines the type of relationship states develop as central organizations of the political system with their internal periphery (other political organizations) and with organizations of other functional systems, for example the economy (Luhmann, 2000b, p. 244; Tacke, 2011, p. 105). Through organizations, more specifically through state bureaucracies, states try to control social order or other social spheres on their territory, using law and money as the main means of communication. States use organisational power to control other organisations such as companies, universities, NGOs etc. or to control the effects of globalisation on their territory. They also need organisational power if they want to control the internet within the borders of the state territory.

As a matter of fact, in many parts of the world political regimes and their states instrumentalize functional differentiation for political ends. But this does not mean that they are able to create through organisational power something new, an alternative form of social differentiation. States may present themselves as "organized societies" and in extreme cases as societies to be "revolutionized" under the guidance of a single party-organization (Luhmann, 2000a, p. 384). Non-democracies in a post-cold war context can no longer realize the power structure the former communist party-states could organize. Still they are variations on a combination of power features by means of which incumbents can retain power and exploit functional differentiation by controlling society, for example through informal structures such as quasi-institutionalized corruption, manipulation of electoral procedures, repression (of the opposition!) or the instrumentalization of the legal system. Typically, in such regimes a dominant organization (for example a political party) controls organizations of the economy, the media or civil society through networks of clientelism and corruption. Old-new distinctions such as friends and enemies or loyal and disloyal conceal, so to speak, the established differences of the functional systems, for example the distinction legal/illegal, which can be dealt with in an opportunistic manner in the absence of a state based on the rule of law. And considering that corruption and autocracy are institutionalized practices in many countries, we may expect many non-democratic regimes to experiment not only with imitation of democracy but also with emulation of older forms of differentiation such as stratification, with the ruling "class", "clan" or "family" at the "top" of society.

Functional differentiation with all its opportunities (access to world markets!) is the necessary background for all kinds of "secondary" forms of differentiation in non-democracies such as oligarchies, networks of power, clan systems or feudal-like "crony capitalist" corruption networks (Nielsen, 2003). But these social structures or practices also represent parasitical forms of differentiation which may potentially affect the autonomy of functional systems in a specific region. On the other hand it may be that anti-modern structures are persistent in such regimes - but so are the practices "deviating" from the expectations of the organized society, practices "from the bottom up" using their own networks to cope with, to avoid or to beat the "system". 
Ultimately, what can be seen is not an alternative to functional differentiation and the modernity it stands for. Particularly in the post-Soviet "East", no alternative to the "West" shows its flags: politically speaking, political regimes may see that differently, since they have to defend their power positions, including their corrupt and predatory practices in the regional society they pretend to control. Hybrid non-democracies are basically parasites of functional differentiation. As such, they may successfully combine "neo-traditional" forms of informal power with modern organizational governance capacities. On the other hand one can always see that the "emperor is not wearing any clothes", that the established power structures are contingent, artificial and unpredictable — at least that is also what the protests against them, in Russia as well as in other similar regimes, seem to confirm.

\section{Autocracies and Cultures of Informality}

Examining political regimes means examining specific sets of formal and informal institutions and practices, which also implies analyzing how and under what kind of constraints political power is exercised (Köllner, 2012, p. 22). In quasi-authoritarian regimes, the existing power structures produce other combinations of formal and informal politics than in established democracies (Beunen, Van Assche, \& Duineveld, 2015). Steven Levitsky and Lucan Way (2010) point out the importance of informal institutions particularly in regimes with competitive authoritarianism, where "the disjuncture between formal (i.e. democratic) rules and actual behaviour" is inherent to such regimes (p. 27). On that level of regime types, it makes sense to distinguish between democratic and non-democratic types of informality (Meyer, 2006, p. 29). But as a matter of fact, such distinctions only make sense in the context of democratization, where one might find more or less dangerous or illegal informal practices conceived as a hindrance to the development of democracy. In most countries of the post-Soviet space there can be no question of a process of democratization (as optimistic "transitologists" still thought a couple of years ago). The main problem for incumbents is maintaining a stable regime and staying in power. It is not about democracy! In such a context it would also be rather difficult to separate the "good", "democratic" and "complementary" informality from rather "bad" forms of informality, "undemocratic" and "illegal" or even "illegitimate" informal practices. Rather it would make more sense in this context to point to the difference between the field of social regulation and the field of legal rules, between formal rules or the rule of law and the rules of the game (Ortmann, 2011, p. 179; 2003, p. 104). This difference or gap may be more or less wide, a gap pointing to the degree of deviation, the zone of tolerated violation or rules which is or not admitted in a specific context, for example in Russia, where according to Ledeneva (2013) formal and informal constraints form in practice "a symbiotic relationship - a co-dependence between official policies and unofficial influences, between overlapping formal hierarchies and intertwined informal networks" (p. 246).

Considerable variations in the cultures of informality can be expected in Eastern Europe. Even in the most advanced countries in the region, which resemble functioning, efficient and liberal democracies based on the rule of law, informal networks of power with a more-or-less tolerated zone of deviation can be observed. However, in the case of the most authoritarian post-Soviet countries, more problematic forms of the blurring of the borders between the formal and the informal and between the "legal" and the "illegal" zones of the violation of rules emerge. One aspect can be found in different forms of organized corruption, which are considered to be key informal institutions in competitive regimes, and which together with patronage and proxy-ownership networks bind "key economic, media, and civil-society actors to governing parties" (Levitsky \& Way, 2010, p. 28). This comes close to what Ledeneva (2013) understands by "systema" in Russia, an encompassing 
structure of networks of power deploying "perverse effects" or undue influence in almost all spheres of society. It would not be sufficient in such cases to say that informal norms prevail over formal ones or that corruption is somewhere in the shadow of formal rules: the networks of power also "steer", as it were, the way formal rules work, and the extent to which they should be applied or enforced. Corruption, clientelism or personalism are just "by-products" of a much larger structure of politico-economic power aiming to "reach out" to society by trying to control the economy, the judicial/legal system, the media and even the education system. Such an encumbrance, produced and reproduced by an authoritarian power structure with its bureaucracies, can be considered as one of the major obstacles to Russia's modernization process (Jonson \& White, 2012; Pain, 2012; Ledeneva, 2013).

In such regimes the established state and market structures simply ignore the normative importance of the state/society distinction as a guarantee of individual freedom. In the case of Russia, for example, society does not seem to be something that could be thought of as being independent from state control. On the contrary, society is rather an extension of the state. Individual freedom and private interests are not really placed on the level of inviolable rights; rather they are provided only insofar as state interests are not affected. Russia functions like a large bureaucratic corporation, "Russia Inc.", combining highly personalized leadership structures with organizational power and networks of power (friends, loyalties, clients) instrumental in keeping incumbents in power. That markets, the rule of law and state bureaucracies cannot function the way they should in a modern society is rather obvious in an extremely exclusive and inegalitarian system, where privileges, annuities and organizational power are distributed in exchange for political loyalty. Such power structures based on organization and networks exploit the functional differences of modern society in the sense that they instrumentalize them through their personalized networks: having friends in the right positions is helpful and indeed indispensable if you want "to get things done", be it in the judicial system, in banks and companies, in parliaments, or in NGOs. Old-new distinctions such as friends and enemies or loyal and disloyal conceal, so to speak, the established differences of the functional systems, for example the distinction between the legal and the illegal, which can be dealt with in an opportunistic manner in the absence of a rule-of-state based state. Obviously such a system cannot survive without corruption. And it is evident that, here, corruption inevitably means de-differentiation. ${ }^{5}$ Of course it is de-differentiation only for those who are not part of the corresponding networks. For those participating in the networks it is a question of having friends in the right places in order to obtain access to or to maintain control of assets. ${ }^{6}$ Such configurations of informal and formal structures reveal typically a difference between what outside observers of the "system" identify as corruption or a problem of rule of law and observers in the "system" focussing on "getting things done" or economic interests (Van Assche, Breunen, \& Duineveld, 2014, p. 23).

\section{Formal Rules and Legal Nihilism}

In such a context the limits of the formal/informal distinction become clearly visible-practically

\footnotetext{
${ }^{5}$ In an interview with William Rasch (2000, p. 204), Niklas Luhmann observes that "corruption is also a dedifferentiation. You have a network of relations, of favours, and of legitimate or illegitimate manoeuvring of resources that is dominant in society, then you decide, within this network, whether you should use legal or illegal means, or whether you should favour this one or that one, or whether the big families of the country use their own network to integrate their firms or not".

${ }^{6}$ It can be easily seen that such friendships are instrumental or utilitarian. Particularly among the ruling elites in transition and / or quasi-authoritarian regimes in Eastern Europe, such friendships do not necessarily point to the same type of communities as those described by anthropologists (Kaser, 2001).
} 
meaningless, since the quasi-authoritarian regime can use a "politicized" and instrumentalized legal and judicial apparatus in order to produce legal norms (the formal side) that protect the interests of a highly informal power structure. $^{7}$ Autocratic regimes are particularly obsessed with regulating all sorts of (deviant) behavior they dislike for obvious and less obvious reasons: the risk of losing power to a more-or-less organized opposition is always taken into account by the incumbents of power. Or such regimes may simply be "anti-western" and in need of an enemy in order to "legitimize" their power, and hence they have to enforce laws that proscribe certain forms of conduct as deviant. ${ }^{8}$ Using the law against the opposition and "enemies" is a core feature of such regimes. ${ }^{9}$ They may also "formalize" their own informal practices, which would underline once more that behind the formal/informal distinction might be nothing more than a kind of legal opportunism. Therefore, in a context of legal nihilism, as one might describe the misuse of law for and by particular interests of politicians or officials, the formal and the informal are exchangeable. That is what James L. Gibson (2004) has in mind when speaking about Soviet officials treating "the law as an instrument to be embraced when useful and ignored when expedient" (p. 81). This instrumental conception is also expressed in the proverb: "The law is like the shaft of a wagon; it goes wherever you turn it" (Kahn, 2010, p. 162).

This is even more apparent in Putin's Russia, where the syndrome of "legal nihilism" implies a culture of a lack of respect for the law, particularly on the level of political elites. "Russia has one of the lowest levels of respect for rules and norms in Europe, both formal (the law) and informal (religious, family, traditional ethnic, etc.)" (Pain, 2012, p. 106). This "tradition" of a lack of respect for the law together with other factors, such as the poor quality of the law and too many laws in the hands of excessively powerful state officials working for an oversized central bureaucracy are considered the main causes of corruption in Russia (Holmes, 2012, p. 204; Pain, 2012, p. 108).

These remarks on the lack of respect for the law point to another problematic aspect of the use of the formal/informal distinction: this normativity does not only exist on one side of the distinction, the formal one; rather it is to be found on both sides. Social life is always made up of a combination of social norms and legal rules, both informal and formal ones, as Denis J. Galligan (2003, p. 14) rightly observes. The interesting question then is how the two sorts of rules communicate or to what extent they are in conflict with each other. With regard to legal norms and particularly to the normative character of the rule of law principle, this would imply the question as to "under which social conditions the rule of law could become accepted by society as one of its social norms" (Galligan, 2003, p. 19). The legal nihilism or legal opportunism syndrome prevalent in some countries of the former Soviet Union points to the absence of those conditions and it shows that the distinction between formal and informal norms is, in fact, part of a larger normative context in which expectations on the programmatic level of states (state laws), as well as at the individual level, have to be

\footnotetext{
7 In this regard, Gel'man (2012) using the notion of subversive institutions to describe the penetration of formal institutions by parasitic informal institutions

${ }^{8}$ Lauderdale (2011), who considers the integration of the study of power essential to an approach to political deviance (p. 341).

9 In this regard, O'Donnell (2004) quotes two famous lines expressing precisely this aspect of quasi-authoritarian regimes: "For my friends, everything; for my enemies, the law." And "To be powerful is to have [legal] impunity", expressing the old Latin American tradition of ignoring the law - a "tradition" particularly widespread among the privileged. A description more than appropriate for the Russian case.

10 Holmes (2008), referring to Medvedev's speech of February 2008. "Legal nihilism” is obviously a contested concept (p. 1013). But despite being aware of the fact that there are other narratives of Law, even or particularly in Russia, one may see in this specific discourse of "legal nihilism" a critique of the way the Russian State and its members are looking at law and its normativity. Such a "top down" perspective is complementary to the "bottom up" perspective of normal citizens looking at law in a cynical way (Hendley, 2012, 2015; Popova, 2012; Solomon, 2012).
} 
confirmed and reproduced in daily interactions. One may come up with the idea of better and more efficient laws, as Medvedev suggested, in order to overcome this legal nihilism. But as long as the idea of a law-based society is absent, with the law regarded primarily as a tool in the hands of political power, as long as the independence of the judiciary is nonexistent, or large parts of the state bureaucracy are seen as corrupt, such calls are rather irrelevant and divert the attention of the public from the fact that this state first of all needs a rule of law at the fundamental level and not just better laws (Solomon, 2012).

In this regard Ledeneva (2013), in her discussion of "systema" in Russia, observes that "the complexity of the rules and the selective nature of their enforcement-grasped in a formula of "over-regulation and under-enforcement" - compel[s] the majority of Russians, willingly or unwillingly, to violate them (p. 14). The whole economy operates in the mode of 'legal nihilism', so that everyone is bound to disregard at least some laws". This is a far cry from what citizens should be able to expect from the rule of law: a certitude about the rules of the game and the universal enforcement of rules. That brings us back to James Scott's (1998) observation that formal order is always parasitic on informal processes. Order always reproduces disorder. One may add that in an authoritarian order such as Russia, the established power structure increases social disorder by the very fact of its inefficient "antimodern" network structures. A modern society cannot be "controlled" by a combination of political organizations and networks. Any attempt to do so produces unpredictable deviation. One of the important lessons of the failure of communism was always that the obsession with unity necessarily produces differences - be it on the microsociological level or on the meso level. Attempts "from above" to "bureaucratize", control or repress social life and the unavoidable deviation in society produce deviation "at the bottom level" and strategies dealing with the question of how to best avoid or go against inefficient rules or the pretentions of an informal power structure. To a certain degree this may also be the case in established Western democracies or the so-called new democracies of the EU, but in the post-Soviet space, particularly in quasi-authoritarian countries such as Russia, we find a much more troubling picture of publicly uncontrolled control of informal deviation at the level of the central power structure.

\section{Conclusion}

At the end of this short journey across the landscapes of use and abuse of political power in non-democracies of the post-Soviet type it would be difficult to see in the abovementioned informal power networks or in their combination with organizational systems new forms of differentiation. At most we can see how political elites are "exploiting" the potential and dynamics of functional systems and their organizations for political and economic objectives. World market prices for oil and gas being high, authoritarian experiments can survive for a while. On the other hand, such authoritarian structures always have an artificial character too: one does not really know why they are there and why they govern the way they do. The protest against the Russian way of governing through informal networks has pointed precisely to this reality: that a modern (regional) society needs adequate systems of knowledge in all social spheres in order to be able to be competitive, to modernize etc. The established power networks in the post-Soviet space are light years away from such considerations. The regime's main "operational mode" is a "neo-traditional" power structure in the context of modern society. Its main means of action could be described as acting as parasites of functional differentiation.

A tentative look at how the regime deals with, tolerates and controls informal deviation could possibly point to the following three points. First there is the acceptance by the elites of the established informal system 
of power with its rules of the game, because this is what allows these elites to retain political power: the rules of the game include the tolerance of informal deviation with all its more-or-less illegal variants, such as widespread corrupt practices, but also the use of formal norms to control informality or "deviant players". Then one may also expect a much higher level of unpredictable and arbitrary tolerance of deviation by the authorities with regard to formal rules and their application and enforcement on the part of the public. Finally, one can observe and expect considerable repression of forms of informal deviation understood in the sense of collective resistance against the established informal power structures and practices. One can easily see here the work of "double standards": the freedom to manoeuvre and licence to "deviate" for those included in the "system" and use of the "legal weapon" against those who are outside of it or who do not respect the rules of the game, whether in bureaucracies, companies or in public life.

\section{References}

Beunen, R., Van Assche, K., \& Duineveld, M. (Eds.). (2015). Evolutionary governance theory: Theory and applications. Cham: Springer.

Christiansen, T., \& Neuhold, C. (Ed.) (2012). International handbook on informal governance. Edward Elgar Publishing, London.

Conrad, B. (2006). Informal politics. Hamburg Review of Social Sciences, 1(3), 256-271.

Crozier, M., \& Friedberg, E. (1977). L'Acteur et le système. Seuil, Paris.

Galligan, D. J. (2003). Legal failure: Law and social norms in post-communist Europe. In D. J. Galligan and M. Kurkchiyan (Eds.), Law and informal practices: The post-communist experience (pp. 1-23). Oxford: Oxford University Press.

Gallina, N., \& Hayoz, N. (2011). The relevance of informal power in Eastern Europe. In N. Hayoz, L. Jesien and D. Koleva (Eds.), 20 years after the collapse of communism (pp. 119-141). Bern, Lang.

Gel'man, V. (2012). Subversive institutions and informal governance in contemporary Russia. In T. Christiansen and C. Neuhold (Eds.), International handbook on informal governance (pp. 135-153). London: Edward Elgar Publishing.

Gibson, J. L. (2004). Russian attitudes towards the rule of law: an analysis of survey data. In D. J. Galligan and M. Kurkchiyan (Eds.), Law and informal practices. The post-communist experience (pp. 77-92). Oxford University Press, Oxford.

Gudkov, L. (2012). Sozialkapital und Werteorientierung Moderne, Prämoderne und Antimoderne in Russland. Osteuropa, 62(6-8), $55-83$.

Helmke, G., \& Levitsky, S. (2004). Informal institutions and comparative politics: A research agenda. Perspectives on Politics 2(4), 725-740.

Hendley, K. (2012). Who are the legal nihilists in Russia? Post-Soviet Affairs, 28(2), 149-186.

Hendley, K. (2015). Resisting multiple narratives of law in transition countries: Russia and Beyon. Law and Social Inquiry, 40(2), 531-552.

Inglehart, R. (2012). Modernization and democracy. In V. Inozemtsev and P. Dutkiewicz (Eds.), Democracy versus modernization. A Dilemma for Russia and for the world (pp. 123-144). Routledge, London.

Jonson, L., \& White, S. (Eds.) (2012). Waiting for reform under Putin and Medvedev. Palgrave Macmillan, Basingstoke.

Holmes, L. (2008). Corruption and organised crime in Putin's Russia. Europe-Asia Studies, 60(6), 1011-1031.

Holmes, L. (2012). Crime and corruption. In G. Gill and J. Young (Eds.), Routledge handbook of Russian politics and society (pp. 198-208). Routledge, London.

Kahn, J. (2010). The rule-of-law factor. In J. Newton and W. Tompson (Eds.), Institutions, ideas and leadership in Russian politics (pp. 159-183). Palgrave, Basingstoke.

Kaser, K. (2001). Freundschaft und Feindschaft auf dem Balkan. Wien, Wieser.

Köllner, P. (2012). “Informelle Politik” und “informelle Institutionen”: Konzeptionelle Grundlagen, analytische Zugänge und Herausforderungen für das Studium autoritärer und anderer politischer Herrschaftssysteme. GIGA Working Papers No. 192 ( pp. 1-33). Retrieved August 30, 2013, from http://www.giga-hamburg.de/workingpapers

Lauderdale, P. (2011). Political deviance. In C. D. Bryant (Ed.), The Routledge handbook of deviant behavior (pp. 337-343). Routledge, London.

Ledeneva, A. V. (2013). Can Russia modernise? Cambridge University Press, Cambridge. 
Levitsky, S., \& Way, L. A. (2010). Competitive authoritarianism. Hybrid regimes after the Cold War. Cambridge University Press, Cambridge.

Luhmann, N. (1982). The differentiation of society. Columbia University Press, New York.

Luhmann, N. (1990). Essays on self-reference. Columbia University Press, New York.

Luhmann, N. (2000a). Organisation und Entscheidung. Westdeutscher Verlag, Opladen.

Luhmann, N. (2000b). Die Politik der Gesellschaft. Frankfurt a. M.: Suhrkamp.

Luhmann, N. (2012). Theory of society, volume 1 (= English translation of Luhmann 1997, vol.1). Stanford: Stanford University Press.

Meyer, G. (2006): Formal and informal politics: questions, concepts and subjects. In G. Meyer (Ed.), Formal institutions and informal politics in Central and Eastern Europe: Hungary, Poland, Russia and Ukraine (pp. 9-145). Barbara Budrich Publishers, Opladen.

Misztal, B. (2000). Informality. Social theory and contemporary practice. Routledge, London.

Morin, E. (2008). La méthode I et II. Seuil, Paris.

Mommsen, M., \& Nussberger, A. (2009). Das system Putin. Beck, München.

Nielsen, R. P. (2003). Organization theory and ethics: Varieties and dynamics of constrained optimization. In H. Tsoukas, C. Knudsen (Eds.), The oxford handbook of organization theory (pp. 476-501). Oxford University Press.

O'Donnell, G. A. (2004). Why the rule of law matters. Journal of Democracy, 15(4), 32-46.

Olivier de Sardan, J. P. (2013). The informal practices of civil servants. In N. Cheeseman, D. Anderson, A. Scheibler (Eds.), Roudledge handbook of African politics (pp. 59-69). London: Routledge,.

Ortmann, G. (2003). Regel und Ausnahme. Paradoxien sozialer Ordnung, Suhrkamp, Frankfurt.

Ortmann, G. (2011). Kunst des Entscheidens. Velbrück Wissenschaft, Weilerswist.

Pain, E. (2012). Socio-cultural factors and Russian modernization. In L. Jonson and S. White (Eds.), Waiting for reform under Putin and Medvedev (pp. 96-116). Palgrave, Basingstoke,.

Popova, M. (2012). Politicized justice in emerging democracies: A study of Courts in Russia and Ukraine. Cambridge, Cambridge University Press

Rasch, W. (2000). Niklas Luhmann's modernity. The paradoxes of differentiation. Stanford University Press, Stanford, CA.

Rose, R. (2000a). Uses of social capital in Russia: modern, pre-modern, and anti-modern. Post-Soviet Affairs, 16, $33-57$.

Rose, R. (2000b). Getting things done in an antimodern society: Social capital networks in Russia. In P. Dasgupta and I. Serageldin (Eds.), Social capital, World Bank (pp. 147-169), Washington, D.C.

Scott, J. C. (1998). Seeing like a state. Yale, New Haven, CT.

Scott, J. C. (2012). Two cheers for anarchism. Princeton University Press, Princeton, NJ.

Solomon, P. H. (2012). Law courts and human rights. In G. Gill and J. Young (Ed.), Routledge handbook of Russian polics and society (pp. 186-197). London: Routlege.

Steinsdorff, S. V. (2005). Gute und schlechte Informalität? Informelle Politik in West und Ost. Osteuropa, 55, 5-16.

Tacke, V. (2011). Soziale Netzwerkbildungen in Funktionssystemen der Gesellschaft. Vergleichende Perspektiven. In M. Bommers and V. Tacke (Eds.), Netzwerke in der funktional differenzierten Gesellschaft (pp. 89-118). Wiesbaden: VS Verlag für Sozialwissenschaften,.

Van Assche, K., Raoul, B., \& Martijn, D. (2014). Evolutionary governance theory. New York, Springer. 